\title{
Phytochemical and Antitrypanosomal Studies of Different Solvents Extracts of Boswellia dalzielii
}

\author{
Sunday E. Atawodi (Corresponding author) \\ Biochemistry Department, Ahmadu Bello University, Zaria, Nigeria \\ Tel: 234-8033-850-613 E-mail: atawodi_se@yahoo.com \\ Joy Joseph-Idrisu \\ Biochemistry Department, Ahmadu Bello University, Zaria, Nigeria \\ Uche Samuel Ndidi \\ Biochemistry Department, Ahmadu Bello University, Zaria, Nigeria \\ Tel: $234-803-2679-758$ \\ Lazarus MD Yusufu \\ Surgery Department, Ahmadu Bello University Teaching Hospital, Zaria, Nigeria
}

Tel: 234-803-5930-547

Received: September 16, 2010 Accepted: September 30, 2010 doi:10.5539/ijb.v3n2p179

\begin{abstract}
Solvent extracts of the various parts of Boswellia dalzielii (leaves, stem bark and root bark) were screened in vitro and in vivo for antitrypanosomal activity against Trypanosoma brucei brucei. Methanolic extract of the leaves, stem bark and root bark of Boswellia dalzielii at $20 \mathrm{mg} / \mathrm{ml}$ caused motility to cease after 35, 20 and 20 minutes, respectively while at $10 \mathrm{mg} / \mathrm{ml}$, motility ceased at 50,30 and 20 minutes respectively. Chloroform extract of root bark of the plant caused motility to cease after 40 minutes at concentration of $20 \mathrm{mg} / \mathrm{ml}$. In vivo activity of methanol extract of the plant on T. brucei brucei infected mice showed consistent parasitemic suppressions at $300 \mathrm{mg} / \mathrm{kg}$ with methanolic extract of the leaves displaying highest activity. Reagent-based chemical analysis conducted on the extract revealed the presence of saponins, alkaloids, flavonoids, tannins, resins, steroids and triterpenes. These findings suggest that methanolic extract of Boswellia dalzielii leaves is more effective than other parts of the plant, and hence deserve further evaluation in the therapy of trypanosomiasis.
\end{abstract}

Keywords: Phytochemical, Antitrypanosomal, Solvents extracts, Boswellia dalzielii, T. brucei brucei

\section{Introduction}

Trypanosomiasis is a potentially fatal disease of human and domestic animals in tropical Africa and South America (Fairlamb, 1982). It has undergone a dramatic and devastating resurgence in recent years (Smith et al., 1998) especially in Sub-Saharan Africa (Welburn et al., 2001). Atawodi (2005) noted that the significance of trypanosomiasis to human health, nutrition and economy is enormous, thereby necessitating continuous research for better ways of eliminating the disease. Unfortunately, the scarcity of compounds, the high incidence of side effects, and the emergence of resistance strains have rendered existing chemotherapy, inadequate (Atouguia \& Costa, 1999). Therefore, there is need to explore other agents, especially of plant origin for new generations of anti-trypanocidal agents that are more effective, less toxic, and readily available at cheaper prices.

From early times, plants and plant products have been the primary source of food, shelter and transport materials, clothing, fragrances, flavors and ingredients of medicinal substances for mankind. There have been reports that a vast majority of the population particularly those living in villages largely depend on herbal medicines (Gupta, 1994). According to Sülsen et al. (2007), natural products are important sources of new drugs because their 
derivatives are extremely useful as lead structures for synthetic modification and optimization of bioactivity.

Boswellia dalzielii Hutch (family: Burseraceae), a tree of the Savanna forest of Nigeria has long been known for its medicinal purposes. The bark of Boswellia species yields a whitish gum resin, olibanum or frankincense, which has been extensively evaluated for its medicinal and therapeutic potentials. This spurred interest in other parts of the plant. But, aside from report of Atawodi (2005) which indicated that Boswellia dalzielii had antitrypanosomial activity in vitro there are hardly other reports on the antitrypanosomial properties of the plant. Hence this work was undertaken to evaluate the in vivo antitrypanosomal effects of extract of the plant as well as identify the major classes of phytochemicals present in its methanolic extract.

\section{Materials and Methods}

\subsection{Plant material}

Fresh parts of the plant were collected randomly from Shika and Samaru, Zaria, Kaduna State, Nigeria. The Herbarium unit of the Department of Biological Sciences, Ahmadu Bello University, Zaria, confirmed the taxonomic identity of the plant, and a specimen with voucher $\mathrm{Nr} 1042$ was preserved. Fresh plant material were rapidly washed under running tap water, air dried until brittle and then homogenized to fine powder and stored in airtight bottles.

\subsubsection{Preparation of Plant Extract}

Fifty grams $(50 \mathrm{~g})$ each of the pounded dried plant materials were weighed into different conical flasks and sequentially extracted with $250 \mathrm{ml}$ each of petroleum ether, chloroform, methanol and water, using the mechanical shaker. The extracts were dried in vacuo with the exception of the aqueous extract, which was evaporated on the water bath at $50^{\circ} \mathrm{C}$. All extracts were then stored in the refrigerator at $4^{\circ} \mathrm{C}$ until required.

\subsection{Test Organisms and Animals}

Trypanosoma brucei brucei was obtained from stabilates maintained at the National Institute for Trypanosomiasis Research (NITR) Vom, Plateau State, Nigeria. The parasite was maintained in the laboratory by continuous passage in rats until required. Passage was considered necessary when parasitemia was in the range of $16-32$ parasites per field (usually 3 - 5 days post infection). In passaging, $1 \times 10^{3}$ parasites were introduced intraperitoneally or intramuscularly into rats in $0.1-0.2 \mathrm{ml}$ blood/PBS solution. For several passages, approximately $80 \%$ blood solution ( $\mathrm{v} / \mathrm{v})$ was obtained by cardiac puncture into $1 \mathrm{ml}$ syringe containing $0.2 \mathrm{ml}$ EDTA $(1 \% \mathrm{w} / \mathrm{v})$. About $0.1-0.2 \mathrm{ml}$ of the blood collected as described above or blood (diluted with PBS to contain approximately $1 \times 10^{3}$ parasite $/ \mathrm{ml}$ ) was injected into healthy rats acclimatized under laboratory condition for at least two weeks.

Apparently healthy male albino mice of 3-4 weeks of age, weighing between 20-25g, were used for in vivo studies. The mice were purchased from the Department of Pharmacology, Ahmadu Bello University, Zaria, Nigeria. The mice were maintained on a commercial mice chow and water ad libitum. They were housed in groups of three (3) and given two weeks to adapt to the new environment of the laboratory before being used in the experiment.

The volume of extract to be administered was calculated based on the body weight; the course of parasitemia was followed, and treatment commenced when parasitemia was 1-2 organism per fields, by intramuscular injection.

\subsection{In vitro test for antitrypanosomal effects}

Exactly $10 \mathrm{mg}$ of different solvent extracts of the plant were weighed into Eppendorf tubes and first dissolved in $100 \mu \mathrm{l}$ of $10 \%$ dimethylsulfoxide (DMSO) in PBS. Phosphate buffered saline $(400 \mu \mathrm{l})$ was then added to produce extract solutions of $20.0 \mathrm{mg} / \mathrm{ml}$ (stock). Another extract concentration $(10.0 \mathrm{mg} / \mathrm{ml})$ was prepared from the first extract solution by appropriate dilution with PBS. Aqueous extracts were dissolved directly in $500 \mu 1$ PBS. Extract solutions were prepared just before use.

Assessment of in vitro anti-trypanosomal activity was performed in triplicates in 96 wells micro titer plates (Flow laboratories Inc., McLean, Virginia 22101, USA). Twenty (20) $\mu \mathrm{l}$ of blood containing about 20 - 25 parasites per field obtained as described under "determination of parasitemia" was mixed with $5 \mu$ of extract solution of $20.0 \mathrm{mg} / \mathrm{ml}$ and $10.0 \mathrm{mg} / \mathrm{ml}$ to produce effective test concentrations of $4 \mathrm{mg} / \mathrm{ml}$ and $2 \mathrm{mg} / \mathrm{ml}$ respectively. To ensure that the effect monitored was that of the extract alone, a set of control was included which contained the parasite suspended in 10\% DMSO only. For reference, tests were also performed with the same concentrations of a standard drug, Diminal ${ }^{\mathrm{R}}$ (445mg diminazene diaceurate $+555 \mathrm{mg}$ phenazone/g, Eagle Chemical Company LTD, Ikeja, Nigeria) - a commercial trypanocidal drug. 
After 5 min incubation in closed Eppendorf tubes maintained at $37^{\circ} \mathrm{C}$, about $2 \mu \mathrm{l}$ of test mixtures were placed on separate microscope slides and covered with cover slips and the parasites observed every five minutes for a total duration of sixty minutes. It should be noted that under this in vitro system adopted, parasites survived for about $4 \mathrm{~h}$ when no extract was present. Cessation or drop in motility of the parasites in extract-treated blood compared to that of parasite-loaded control blood without extract was taken as a measure of antitrypanosomal activity. The shorter the time of cessation of motility of the parasite, the more active the extract was considered to be (Atawodi et al., 2003).

\subsection{In vivo Evaluation of Anti-trypanosomal Activity}

Twenty-four (40) albino mice were infected by intraperitoneal inoculation with $10^{3}$ Trypanosoma $b$ brucei cells. They were divided into eight (8) groups of five (5) animals each and the parasitemia levels were monitored daily. At day seven (7) post-infection, the rats in different groups were intraperitoneally administered with different extracts $(300 \mathrm{mg} / \mathrm{kg}$; twice daily); one group served as a positive control i.e. infected but not treated while another served as a negative control i.e. not infected and not treated. Preliminary experiments had indicated 300 $\mathrm{mg} / \mathrm{kg}$ as the average dose that combines antitrypanosomal efficacy with low toxicologic potential.

\subsection{Determination of Parasitemia}

Parasitemia was monitored in blood obtained from the rat tail, pre-sterilized with methylated spirit. The number of parasites was determined microscopically at x 400 magnification using the "Rapid Matching" method of Herbert and Lumsden (1976). Briefly, the method involves microscopic counting of parasites per field in pure blood or blood appropriately diluted with buffered phosphate saline (PBS, pH 7.2). Logarithm values of these counts obtained by matching with the table of Herbert and Lumsden (1976) is converted to antilog to provide absolute number of trypanosomes per $\mathrm{ml}$ of blood.

\subsection{Reagent-based Analysis of Phytochemical Classes}

The freshly prepared extract was subjected to standard reagent-based phytochemical analyses for different constituents, including alkaloids, flavonoids, tannins, saponins, resins, steroids and triterpenes (Trease \& Evans, 1983).

\section{Results}

The petroleum ether, chloroform, methanol and aqueous extracts of different parts of Boswellia dalzielii were analyzed for their phytochemical contents, as well as their in vitro and in vivo antitrypanosomal activity against $T$. brucei brucei at concentration of $20 \mathrm{mg} / \mathrm{ml}$ and $10 \mathrm{mg} / \mathrm{ml}$. Complete elimination of motility of parasite when compared with control was taken as indices of antitrypanosomal effects.

Table 2 shows that chloroform and petroleum ether extracts of the Boswellia dalzielii (leaves, stem bark and root bark) did not eliminate motility at the different concentrations tested, while methanol extracts (leaves, stem bark and root bark) eliminated motility in T. b brucei within 60 minutes at the different concentrations. Aqueous extract of leaves showed very slight motility at the different concentrations. Although, chloroform extract of the root bark seemingly eliminated motility after 40 minutes for $20 \mathrm{mg} / \mathrm{ml}$ concentration, yet it could only show very slight motility after 55 minutes for $10 \mathrm{mg} / \mathrm{ml}$ concentration (this paragraph should be deleted and replaced with the proceeding ones in red).

Table 2 shows that petroleum ether extracts did not eliminate parasite motility as the leaves and root bark extracts were still very motile after 55 minutes and remained so; however, the stem bark was found to be moderately motile at 40 minutes period. The leaves and stem bark of chloroform extracts remained very motile at both concentrations; although, there was moderate motility for the root bark at $10 \mathrm{mg} / \mathrm{ml}$ concentration but motility was completely eliminated at $20 \mathrm{mg} / \mathrm{ml}$ concentration after 40 minutes. The stem bark and the root bark of aqueous extracts at $10 \mathrm{mg} / \mathrm{ml}$ concentration were still very motile after 55 minutes while the leave extract had moderate motility only at 50 minutes period. At $20 \mathrm{mg} / \mathrm{ml}$ concentration, the parasites showed moderate motility at 50,35, and 55 minutes for leaves, stem bark and root bark respectively. However, the methanol extracts of all parts (leaves, stem bark and root bark) eliminated motility in $T . \quad b$ brucei within 60 minutes; although the time it took for that to occur vary from one part of the plant to another and from one concentration to another.

From the in vivo studies, methanolic extract of leaves, stem bark and root bark have antitrypanosomal activity through intramuscular administration (Figure 1). Figure 1 shows changes in parasitemia following treatment with methanolic extract of different parts of the plant $(300 \mathrm{mg} / \mathrm{kg})$. The graph shows that the root bark and the leaves extract continually reduced the parasitemia level, while the stem bark extract seemed to have resulted in relapse after day 8 . 


\section{Discussion}

The methanol extract unlike the petroleum ether, chloroform and aqueous extract contains alkaloids, flavonoids, tannins while its root bark contains resins in addition (Table 1). This may account for its ability to eliminate motility in T. b. brucei within 60 minutes at the different concentrations (Table 2). This may also account for the very slight motility of aqueous extract of leaves at the different concentrations.

Previous workers (Freiburghaus et al., 1997) have shown that the mean MIC value of common trypanocidal drugs is $10.7 \mathrm{mg} / \mathrm{ml}$ and that agent with MIC value between $5-20 \mathrm{mg} / \mathrm{ml}$ could be regarded as very active. In this study, Boswellia dalzielii was found to be active at 10 and $20 \mathrm{mg} / \mathrm{ml}$, which is comparable to the value reported for standard trypanocidal drug.

The fact that the plant showed differential activity between extracts and between parts is confirmation of earlier report (Atawodi et al., 2003), that any statement on a plants trypanocidal activity should be taken within the context of the plant part and the solvent extract tested.

It is difficult to speculate the mechanism by which these extracts exhibit their antitrypanosomal activity since the active ingredient(s) were not isolated. However, accumulated evidence (Sepulveda-Boza \& Cassels, 1996) suggest that many natural products exhibit their antitrypanosomal activity by virtue of their interference with the redox balance of the parasites acting either on the respiratory chain or on the cellular defenses against oxidative stress. This is because natural products possess structures capable of generating radicals that may cause peroxidative damage to trypanothione reductase that is very sensitive to alterations in redox balance. It is also known that some agents act by binding with the kinetoplast DNA of the parasite. The antitrypanosomal principles of the plant tested in this study is unknown, until further studies are carried out.

In vivo assays usually provide relatively reliable information of determining the extracts sensitivity on trypanosome isolates and the use of laboratory mice has the advantage of being relatively inexpensive with respect to cost of animals, housing and maintenance. However, mouse assays are considered to provide only a broad indication of the level of sensitivity of a trypanosome population (Sones et al., 1988). Therefore, this result only suggests that Boswellia dalzielii has potential to provide therapeutic agents for treatment of African trypanosomiasis, and must be subjected to further evaluation before any definite statement can be made on its suitability as antitrypanosomal agent.

\section{References}

Atawodi, S. E. (2005). Comparative in vitro trypanocidal activities of petroleum ether, chloroform, methanol and aqueous extracts of some Nigerian Savannah plants. African Journal of Biotechnology, 4(2), 177-182.

Atawodi, S. E., Bulus, T., Ibrahim, S., Ameh, D. A., Nok, A. J., Mamman, M., \& Galadima, M. (2003). In vitro trypanocidal effect of methanolic extract of some Nigerian savannah plants. African Journal of Biotechnology, 2(9), 317-321.

Atouguia, J., \& Costa, J. (1999). Therapy of human African trypanosomiasis: Current situation. Mem Instituto Oswaldo Cruz Riode Janeiro, 94(2), 221 - 224.

Fairlamb, A. (1982). Biochemistry of trypanosomiasis and rational approaches to chemotherapy. TIBS (July), 23-26.

Freiburghaus, F., Jonker, S. A., Nkuna, M. H. N., Mwasunbi, L. B., \& Brun, R. (1997). In vitro trypanocidal activity of some rare Tanzanian medicinal plants. Acta Tropica, 67, 181-185

Gupta, S. S. (1994). Prospect and perspectives of Natural Plants Products in medicine. Indian Journal of Pharmacology, 26, 1-12

Herbert, W. J., \& Lumsden, W. H. (1976). Trypanosoma brucei: a rapid "matching" method for estimating the host's parasitemia. Exerimental Parasitology, 40, 427-431

Sepulveda-Boza, S., \& Cassels, B. K. (1996). Plant metabolites active against Trypanosoma cruzi. Planta Medica, 62, 98-105

Smith, D. H., Pepin, J., \& Stich, A. H. R. (1998). Human African trypanosomiasis: an emerging public health crisis. British Medical Bulletin, 54, 341-355

Sones, K. R., Njogu A. R., \& Holmes, P. H. (1988). Assessment of sensitivity of T. congolense to isometamidium chloride: comparison of tests using cattle and mice. Acta Tropica, 45, 153-164

Sülsen, V. P., Cazorla, S. I., Frank, F. M., Redko, F. C., Anesini, C. A., Coussio, J. D., Malchiodi, E. L., Martino, V. S., \& Muschietti, L. V. (2007). Trypanocidal and Leishmanicidal activities of Flavonoids from Argentine 
Medicinal Plants. American Journal of Tropical Medicine and Hygiene, 77 (4), 654-659

Trease, G. E, \& Evans, M. C. (1983). Textbook of Pharmacognosy (12th ed.) London: Bailiere, Tindal. pp. 343-383.

Welburn, S. C., Coleman, P. G., Fevre, E., \& Mandlin, I. (2001). Sleeping sickness - a tale of two diseases. Trends in Parasitology, 17, 19 - 24.

Table 1. Phytochemical constituents of leaves, stem bark and root bark of Boswellia dalzielii

\begin{tabular}{|l|l|l|l|l|l|l|l|l|l|l|l|l|}
\hline \multirow{2}{*}{ Constituents } & \multicolumn{3}{|c|}{ Petroleum ether extract } & \multicolumn{3}{c|}{ Chloroform extract } & \multicolumn{3}{c|}{ Methanolic extract } & \multicolumn{3}{c|}{ Aqueous extract } \\
\cline { 2 - 13 } & Leaves & $\begin{array}{l}\text { Stem } \\
\text { bark }\end{array}$ & $\begin{array}{l}\text { Root } \\
\text { bark }\end{array}$ & leaves & $\begin{array}{l}\text { Stem } \\
\text { bark }\end{array}$ & $\begin{array}{l}\text { Root } \\
\text { bark }\end{array}$ & leaves & $\begin{array}{l}\text { Stem } \\
\text { bark }\end{array}$ & $\begin{array}{l}\text { Root } \\
\text { bark }\end{array}$ & $\begin{array}{l}\text { leaves } \\
\begin{array}{l}\text { Stem } \\
\text { bark }\end{array}\end{array} \begin{array}{l}\text { Root } \\
\text { bark }\end{array}$ \\
\hline Alkaloids & 0 & 0 & 0 & 0 & 0 & 0 & ++ & ++ & ++ & 0 & 0 & 0 \\
\hline Flavonoids & 0 & 0 & 0 & 0 & 0 & 0 & +++ & +++ & +++ & +++ & +++ & ++ \\
\hline Saponins & 0 & 0 & 0 & 0 & 0 & 0 & 0 & 0 & 0 & +++ & ++ & + \\
\hline Tannins & 0 & + & 0 & 0 & 0 & 0 & ++ & ++ & +++ & ++ & ++ & + \\
\hline Resins & +++ & + & ++ & +++ & + & ++ & 0 & 0 & +++ & 0 & 0 & 0 \\
\hline $\begin{array}{l}\text { Steroids and } \\
\text { triterpenes }\end{array}$ & +++ & ++ & +++ & +++ & ++ & + & 0 & 0 & 0 & 0 & 0 & 0 \\
\hline
\end{tabular}

Very reactive, +++ ; Reactive, ++ ; Slightly reactive, + ; No reaction, 0

Table 2. Effect of different concentrations of different solvent extracts of Boswellia dalzielii on motility of Trypanosoma brucei brucei

Time (min) after which motility ceased, reduced drastically *or reduced slightly** with different effective concentration of extract $(\mathrm{mg} / \mathrm{ml})$

\begin{tabular}{|l|l|l|l|l|l|l|l|l|}
\hline & \multicolumn{9}{|l|}{ Solvent/Concentration } \\
\hline & Petroleum ether & Chloroform & \multicolumn{2}{l|}{ Methanol } & \multicolumn{2}{l|}{ Aqueous } \\
\hline Parts of Plant & $20(\mathrm{mg} / \mathrm{ml})$ & $10(\mathrm{mg} / \mathrm{ml})$ & $20(\mathrm{mg} / \mathrm{ml})$ & $10(\mathrm{mg} / \mathrm{ml})$ & $20(\mathrm{mg} / \mathrm{ml})$ & $10(\mathrm{mg} / \mathrm{ml})$ & $20(\mathrm{mg} / \mathrm{ml})$ & $10(\mathrm{mg} / \mathrm{ml})$ \\
\hline Leaves & $55^{* *}$ & $55^{* *}$ & $55^{* *}$ & $55^{* *}$ & 35 & 50 & $50^{*}$ & $50^{*}$ \\
\hline Stem bark & $40^{*}$ & $40^{*}$ & $55^{* *}$ & $55^{* *}$ & 20 & 30 & $35^{*}$ & $55^{* *}$ \\
\hline Root bark & $55^{* *}$ & $55^{* *}$ & 40 & $55^{*}$ & 20 & 20 & $55^{*}$ & $55^{* *}$ \\
\hline
\end{tabular}




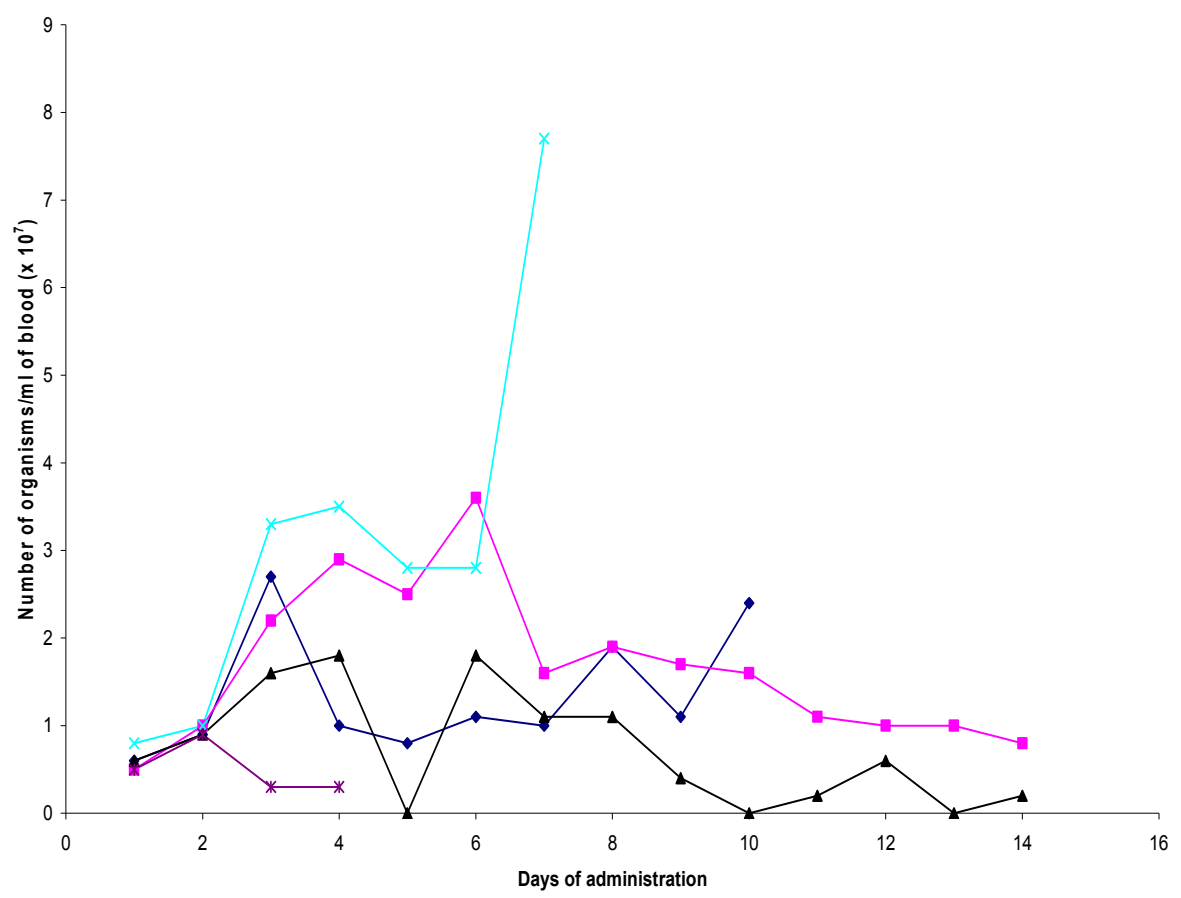

$\rightarrow-$ stem bark $\rightarrow$ - root bark $\rightarrow$ - leaves $\rightarrow$ control $\rightarrow$ standard drug

Figure 1. Changes in Parasitemia following treatment with methanolic extract of different parts of Boswellia dalzielii through intramuscular administration $(300 \mathrm{mg} / \mathrm{kg}$ b.w.) 